\title{
GRADUAL RETIREMENT: PREFERENCES AND LIMITATIONS
}

\author{
BY
}

TUNGA KANTARCI*, ARTHUR VAN SOEST**

\begin{abstract}
Summary
In the traditional retirement scenario, individuals work full-time or part-time until a given age, and then stop working abruptly. From the individual's point of view, it seems more attractive to have a smooth transition, with gradual retirement. In Sweden and other European countries, specific gradual retirement programs have been created in the past 20 years, first in combination with early retirement programs and later to increase labour market participation of older workers. This paper surveys the existing literature on gradual retirement in the US and Europe and analyzes the relevance of gradual retirement in the Netherlands as a tool to keep people employed longer.
\end{abstract}

Key words: partial pension, phased retirement

JEL (codes): J14, J26

\section{INTRODUCTION}

In the traditional retirement scenario, individuals work full-time or part-time until a given age, and then stop working overnight. This fits with the notion of an institutionalized life course with separate stages of labour force preparation, participation and withdrawal (Kohli 1986; Meyer 1986; Mayer and Schoepflin 1989). Labour market rigidities in terms of team production, fixed employment costs and social security incentives or age discrimination are factors that appear to have contributed to this segregation (Mayer and Müller 1986; Hurd 1996; Quinn 1981).

It seems intuitively attractive from the point of view of the individual, however, to have a smooth transition from work to retirement, gradually reducing the number of hours worked. This is also in line with a more recent view on the life-course trajectory: Brüeckner and Mayer (2005) contended that the post-modern epoch identifies "patterns of a greater variety of partly freely chosen, partly imposed life trajectories." Opportunities for gradual reduction of the working effort may also increase opportunities for working after the

\footnotetext{
* Tilburg University, P.O. Box 90153, 5000 LE, Tilburg, The Netherlands, e-mail: kantarci@ uvt.nl.

** Tilburg University, Netspar and RAND, P.O. Box 90153, 5000 LE, Tilburg, The Netherlands, e-mail: avas@uvt.nl.
} 
normal retirement age: many people dislike the idea of continuing the same job with the same effort after this age, but may well be interested in continued participation in the labour market at a reduced effort level.

Gradual withdrawal from the labour force can have two forms (see, e.g., Scott 2004): either phased retirement (reducing work hours in the same job) or partial retirement (changing to a less demanding job with usually fewer hours and lower earnings). Each retirement path comes with its own income trajectories before, during, and after the transition process, with, for example, a combination of wages and a partial state pension and/or occupational pension during the period of gradual retirement.

In the United States, about $18 \%$ of the cohort of salaried workers born between 1931 and 1941 were in phased or partial retirement in 1998 and 2000 (Scott 2004). In Europe, several gradual retirement programs have been created in the past 20 years, first in combination with early retirement programs and later as an attempt to increase the participation rate of the older part of the workforce. In the Netherlands in 2004, about one-third of former and current employees said their (last) employer offered the possibility of phased retirement (Van Soest et al. 2006).

In order to design successful plans that are attractive to older workers, increasing their lifetime welfare, well-being, and contribution to society, it is essential to know the preferences of the workers as well as the considerations of their employers for offering or not offering gradual retirement. It is also essential to know the constraints imposed by state and occupational pension schemes. Institutional restrictions on combining earnings with pension income, or a pension system in which the pension level is determined by final earnings have been shown to severely limit the attractiveness of phased or partial retirement in the US (Chen and Scott 2003).

The relevance of this topic for society and public policy seems obvious. Early retirement programmes and other exit routes that lead to early withdrawal from the labour market imply a burden for the macro-economy, magnified by the ageing of the population, and are therefore at the top of the policy agenda in many countries. Gradual retirement has the potential to improve the lifetime utility of older workers while at the same time increasing labour supply and the sustainability of the pension system. A central issue is the ambiguous effect on total hours worked. Some workers who choose parttime work would otherwise have retired completely, but others would have kept working full-time. The total effect on labour supply depends on which of the two effects is larger.

This paper first surveys the existing micro-economic literature on gradual retirement. It discusses concepts, measurement and prevalence of gradual retirement. It then discusses worker preferences (supply), advantages and disadvantages for employers (demand), and institutional constraints. For an 
international perspective, the paper considers gradual retirement in both the US and a number of European countries.

The paper also specifically looks at the Dutch situation and the relevance of gradual retirement as a tool to keep people longer at work. Increasing the participation rate to $80 \%$ in 2016 is an explicit target of the Dutch government and the unions and employers' associations. While the rise in participation of prime age women has resulted in a rise in the overall participation rate in the past decades, this rise now seems to have come to a standstill (see Sect.6), leaving increasing participation of the elderly as the main alternative. Gradual retirement may be an important tool to make this feasible.

In addition to the literature review, which gives insight in worker preferences, our paper analyses new survey data on the perceptions of Dutch employees of opportunities for gradual retirement at their current employer. Combining these with findings on preferences gives an indication of what is needed to increase the prevalence of gradual retirement and the participation rate of older workers.

The structure of the paper is as follows. Section 2 considers definitions and measurement issues. Section 3 describes the factors facilitating and obstructing gradual reduction of the work effort from the standpoint of both the employee and the employer, looking at theoretical arguments as well as survey evidence. Section 4 focuses on the empirical facts for the US, considering transitions into and out of gradual retirement, and discussing the correlates of gradual retirement identified in the literature. Section 5 looks at gradual retirement in Europe. Section 6 looks specifically at preferences for and access to gradual retirement in the Netherlands. Section 7 concludes.

\section{CONCEPTS AND MEASUREMENT}

Traditional retirement is characterized by a structural break in the late life cycle - from full employment to complete retirement. In contrast, gradual retirement involves a time period during which work activity is reduced, implying a transition process rather than an instantaneous transition (Quinn 1999). The transition into retirement may take various forms (Hayward et al. 1994). The reduction of work can imply a reduction of working hours, hourly wages, or both, in- or outside the career job. Transitions are not always monotonic (from working more to working less), but may be reversible with, e.g., re-entry into a non-career job after spending some time outside the labour market (Hayward et al. 1994). The literature uses a wide range of indicators to identify gradual retirement. These include a reduction in working hours or earnings with an accompanying partial-pension benefit, a change in employer at age 55 or over (implying resignation from the career job), or a subjective qualitative assessment in the form of a self-report. Some measures 
also combine hours or earnings changes with self-reports (Ruhm 1990; Scott 2004), or wages with working hours (Honig 1985).

Gradual, phased, partial and part-time retirement are all different terms used in this context. In this review gradual retirement is used as a generic term to define a gradual withdrawal from the labour market by reducing work effort. Phased retirement is progressive retirement while keeping the same employer within the same system, while partial retirement involves a change in employer. ${ }^{1}$

Phased retirement therefore does not involve change of employer. Examples include downsized work schedules, temporary assignments, consulting work, telecommuting, leave of absence and job-sharing (Reday-Mulvey 1995; Flahaven 2002; Chen and Scott 2003). Partial retirement, on the other hand, involves a change of employer or a shift into self-employment, accompanied by a reduction in working hours or the wage rate (or both) (Gustman and Steinmeier 1983, 1984b, 1986; Honig and Hanoch 1985; Scott 2004).

Another term that is often used in this context is Part-time retirement, defined as at most 34 working hours per week by the US Bureau of Labor Statistics, or as fewer than $1600 \mathrm{~h}$ per year (Quinn 1999), and involves a lower wage. It does not necessarily involve a change of job. A bridge job is defined as a change from the career job (with more than 10 years of tenure) to a new (usually less demanding) job or self-employment (Ruhm 1990; Quinn 1996). Phased and partial retirement are often discussed in relation to flexible retirement, which refers to flexibility in choosing the retirement age, but in the context of an abrupt end to labour force participation (Latulippe and Turner 2000).

Measurement of gradual retirement draws upon the observed or stated labour market status. The former is a quantitative, objective realization of an event such as a reduction in weekly or annual working hours, a reduction in earnings, a change away from the life-long job, or receipt of a partial pension. The latter is based upon a qualitative, subjective assessment by a survey respondent. Surveys often ask the respondents to characterize their job, labour market position or job transition. Numerous objective and subjective measures of gradual retirement have been used in the literature. We briefly discuss them below.

\subsection{Working Hours}

A reduction of working hours is an indication of gradual retirement, although in some cases, the reduction may not be the choice of the worker (Ruhm

1 The existing literature is not consistent in the use of terminology. For example, partial retirement is often used instead of phased retirement (Gustman 1985; Honig 1985; Honig and Hanoch 1985; Ruhm 1990). 
1990). Several thresholds have been used to define part-time work and parttime retirement. The US Bureau of Labor Statistics' measure for a parttime job is at most $34 \mathrm{~h}$ per week. Empirical results appear insensitive to the thresholds (e.g., Blau 1994). Others have defined part-time work on an annual basis. For example, Haider and Loughran (2001) and Scott (2004) used less than $1,750-35 \mathrm{~h}$ for 50 weeks. A rationale to use annual hours is that parttime work may appear as a reduction in weeks per year rather than in hours per week (Quinn 1999).

\subsection{Wage Rates}

Partial retirement typically also involves a transition to a job with a lower wage rate and often has no pension coverage (Gordon and Blinder 1980; Gustman and Steinmeier 1982; Ghent and Clark 2001). Quinn (1999)'s sample of US workers aged 51-65 in 1992-1996 reported a range of wage rates from $\$ 5$ to $\$ 10$ for $60 \%$ of the bridge jobs, but only for $33 \%$ of the career jobs. However, phased retirement can also be associated with a lower wage (Gustman and Steinmeier 1982, 1984a).

\subsection{Earnings}

As a combination of the hourly wage rate and hours worked, earnings provide an attractive measure of gradual retirement. Gustman and Steinmeier (1984b, 2000) defined gradual retirement as a more than $40 \%$ decline in both hours worked and earnings. In data from the early seventies, the peaks in the relative earnings - the ratio of current earnings to maximum earnings - distributions by age and year suggest an alternative threshold of 50\% (Honig and Hanoch 1985).

\subsection{Pension Receipt}

For private pension plans, a partial-pension receipt is an alternative measure of phased retirement. The percentage of the pension that is received is usually the same as the reduction in working hours (an individual reducing work hours by $30 \%$ would thus receive $30 \%$ of the pension benefits in phased retirement) (Latulippe and Turner 2000; Brown 2005). This measure is less useful in the US and several other countries, however, where gradual retirees usually do not have pension coverage (Ruhm 1990; Honig and Hanoch 1985). 


\subsection{Subjective Self-reports of Labour Market Status and Retirement Transitions}

Self-reports have the advantage that they do not require researchers to make arbitrary distinctions between, for example, part-time and full-time work hours. Self-reports also preclude erroneous classification of individuals as partially retired due to involuntary reductions in wages, job demotion or displacement (Ruhm 1990; Chen and Scott 2006), and avoid problems due to missing data on hours, weeks or wage levels required to determine the retirement status (Gustman and Steinmeier 1984a, 1986). A problem with stated gradual retirement can be its inconsistency with objective measurements. For example, respondents report that they are in gradual retirement but have observed earnings at or near previous levels or have not held a job for a substantial amount of time before the survey (Honig and Hanoch 1985; Gustman and Steinmeier 1986). Quinn (1981) compared the subjective account of partial retirement to objective measures, such as labour force status and annual hours worked and concludes that the self-evaluation is generally consistent with the quantitative indicators (see also Gustman and Steinmeier 1984b), but the opposite has also been argued (Murray 1979; Ruhm 1991). Some studies define gradual retirement by supplementing subjective with objective measures on hours (Scott 2004) or earnings (Ruhm 1990).

\section{OBSTACLES AND BENEFITS}

\subsection{Obstacles}

As explained by Scott (2004), the fact that in the US phased retirement is less common than partial retirement suggests that workers face restrictions on phased retirement and often have to find a new job if they want to reduce their work effort. Many restrictions have been suggested in the literature, but there is not much empirical evidence on their quantitative importance.

Hurd (1996) summarized a number of reasons why employers are often reluctant to create opportunities for phased or partial retirement. The first is fixed employer costs, which can be overcome only if the number of working hours is substantial, unless hourly wages are reduced. This may sometimes be possible, but not always (e.g. due to agreements with unions). Another type of restriction is production technology and team production and the difficulty of job scheduling in case of part-time jobs. The third is that reducing hours may make it more difficult to retain job-specific skills (cf., e.g., Morris and Mallier 2003). Investment in on-the-job training is less attractive to the employer for older workers than for younger workers, since workers approaching retirement will not stay with the firm long enough to make the investment pay off. 
This also may explain why some employers are reluctant to hire older workers for jobs that require investing in on-the-job skills.

Gustman and Steinmeier (1984b) already noted that phased retirement would be discouraged if earnings in a year in which the individual works parttime would be counted in determining the pension or social security benefit. A specific financial incentive that makes gradual retirement less attractive is an earnings test on old-age social security benefits that taxes away most of after-tax earnings in a part-time job (cf., e.g., Zweimüller 1993; Ghent and Clark 2001). For example, the US old-age social security benefits that people can claim between age 62 and the normal retirement age are reduced by $50 \%$ for every dollar of earnings above a given threshold, typically reducing the marginal net wage rate of working part-time by the same $50 \%$.

The rules of defined-benefit pension plans are often particularly restrictive. They may, for example, prohibit workers to work for and receive a pension from the same employer at the same time (Chen and Scott 2003; Forman and Scahill 2003). Finally, health insurance may hamper phased or partial retirement or job changes of older workers, particularly if the worker has a chronic health problem (Hurd 1996).

Hutchens and Grace-Martin (2004) showed that restrictions on phased retirement perceived by white-collar workers in the US vary across industries, and that small organizations are more likely to offer phased retirement than larger organizations. Opportunities are largest in health, education, and social services, but are low in the (other parts of the) public administration sector. Expanding establishments offer phased retirement more often than other firms and unionisation reduces phased retirement possibilities (perhaps due to lower downward wage flexibility or reluctance to reduce pension rights; see Smolkin 1996).

Smolkin (1996) presented the results of a survey among Western European personnel executives, asking them which problems they judged to be major obstacles in introducing alternative work patterns, including phased retirement. The results showed a close finish between several reasons, including "hidden extra costs" (named by 32\% of the respondents), "inadequate commitment by top management" (31\%), "production problems" $(30 \%)$, "union opposition" (30\%), "human problems and reactions" (28\%), "resistance by lower- and middle-management" $(28 \%)$ and "inadequate briefing/training to show employees how to take advantage" (27\%). Only $18 \%$ named "lack of support from the workforce."

\subsection{Benefits}

The literature emphasizes the benefits of partial and phased retirement for employees and for the macro-economy as a whole, but also mentions advantages for employers. For employees, gradual retirement "constitutes a way of 
avoiding the pension shock following an abrupt transition from full-time work to full pensioning" (Reday-Mulvey and Delsen 1996). It reduces stress and increases job satisfaction (Reday-Mulvey 2000). It gives the worker an opportunity to benefit from continued membership in a work team, while also providing the free time to develop activities outside work.

Similarly, for employers it provides a soft form of personnel reduction and a cost-effective opportunity to retain people with valuable corporate knowledge and precious skills. Employers can use partial and phased retirement as a means to reduce adjustment costs (Ghent and Clark 2001) and to increase productivity and reduce absenteeism by increasing job satisfaction (RedayMulvey 2000). For firms with their own occupational pension fund, phased retirement may lead to longer contribution periods if workers continue contributing during phased retirement, and to lower average benefits if workers in phased retirement receive partial pensions. Phased retirement may also help to reduce the costs involved with worker exits through alternative exit routes, i.e. disability or unemployment (Reday-Mulvey and Delsen 1996). Smolkin (1996) argued that phased retirement could maintain or even enhance employee morale because a properly promoted phased retirement programme will be perceived as part of a natural evolution rather than a premature career termination.

The macroeconomic benefits focus on labour force participation and the labour supply of older workers. Wadensjö (2006) distinguished three goals in this context: decrease early exit, increase the formal retirement age (or the minimum age for getting an old-age pension), and facilitate work after the normal retirement age. Keeping older workers in the labour force is considered important not only for the size of the labour force, but also because older workers are generally well-qualified and productive, so that keeping them helps to keep productivity per worker at a high level (Mulvey 2005). This is in stark contrast with age discrimination because older workers would be too expensive and less productive.

\section{EMPIRICIAL ANALYSIS OF GRADUAL RETIREMENT IN THE US}

This section first discusses the prevalence of gradual retirement, considering incidence, transition probabilities, sequences and durations. It then reviews the literature on the background characteristics that are correlated with gradual retirement, using the terminology introduced in Sect. 2.

The empirical literature in the US is based mainly upon a few surveys. The Retirement History Study (RHS; see, for example, Irelan (1988)) interviewed men and unmarried women aged 58-63 in 1969 in six biennial waves. The study provided only subjective information on whether the main job offered an opportunity for gradual retirement (Gustman and Steinmeier 1984b). The Health and Retirement Study (HRS) is an ongoing study that began with an 
interview of the cohort aged 51-61 in 1992 and has by now seven biennial waves. Unlike the RHS, it includes also married women. Other cohorts were added later to the study. The RHS and HRS cover retirement, labour force history, demographics, health, income, etc. The National Longitudinal Survey of Older Men (NLS) surveyed men aged 45-59 initially in 1966, and then about every other year, until 1981. The topics included non-work- and work experiences, health and health insurance, leisure time, and labour market decisions (including job changes, retirement, and re-entry).

A drawback of the biennial surveys is the limited information on job- and labour supply mobility between waves (Blau 1994). The Current Population Survey (CPS) is a monthly survey of household members aged 15 and over, which has been conducted for more than 50 years. Interviews include questions on labour force characteristics, such as work experience, schedules, benefits and earnings, as well as demographic and institutional characteristics. The Retirement Confidence Survey (RCS) is an annual study that began in 1991 on individuals over the age of 25, and explores saving behaviour, retirement, and long-run financial security. The Panel Study of Income Dynamics (PSID) is a longitudinal study of a representative sample of US individuals and their families. In recent years, special supplemental datasets were constructed.

\subsection{Incidence of Gradual Retirement}

Of the employees in the HRS who had at least 10 years of tenure, $14.5 \%$ held a bridge job in 1992. This increased to $29.3 \%$ in 1998 and then fell to $25.3 \%$ in 2002 (Quinn et al. 2006). During the first four waves of the HRS, the share of gradual retirees continuously rose with age, to $15 \%$ at age 64 . Scott (2004) found that in the HRS sample, phased retirement decreased from 7.5 in 1994 to $4.1,4.2$ and $1.3 \%$ in 1996,1998 and 2000 , respectively, while partial retirement rose from 3.7 to $5.5,13.4$ and $15.5 \%$.

Expectations of and interest in gradual retirement, as stated by current employees, seem to exceed the actual gradual retirement rates. In a web survey in 2005, 38\% of employees expressed an interest in gradual retirement (Brown 2005). A 1999 AARP survey suggested that about $80 \%$ of baby boomers aged 33-52 expected to work at least part-time during their retirement, mainly because staying at work is intrinsically interesting $(35 \%)$ or because of the extra income (23\%; Roper Starch Worldwide 1999). In the 1998 RCS survey, $61 \%$ of employees expressed an interest in working after retirement, most of them to improve the quality of their lives and some for their financial situation (Yakoboski et al. 1998; Clark and Quinn 2002). 
TABLE 1 - TRANSITIONS IN THE HRS, 1994-2000

\begin{tabular}{lllllll}
\hline \multicolumn{2}{c}{ To } & & & & \\
\cline { 3 - 6 } & & $\begin{array}{l}\text { Full-time } \\
\text { work }\end{array}$ & $\begin{array}{l}\text { Phased } \\
\text { retirement }\end{array}$ & $\begin{array}{l}\text { Partial } \\
\text { retirement }\end{array}$ & $\begin{array}{l}\text { Full } \\
\text { retirement }\end{array}$ & Total \\
\hline From & Full-time work & 48.63 & 4.48 & 9.05 & 37.85 & 100 \\
& Phased retirement & 38.00 & 18.80 & 7.73 & 35.47 & 100 \\
& Partial retirement & 28.40 & - & 24.46 & 47.14 & 100 \\
& Full retirement & 22.27 & - & 12.59 & 65.14 & 100 \\
\hline
\end{tabular}

Source: (Scott, 2004, Figure 3). Sample of salaried workers in 1992; 4,721 observations. Number of transitions in $\%$ of number in origin state. For example, on average over the four 2-year periods, $48.63 \%$ of those working full-time at a given point in time are still working full-time 2 years later.

\subsection{Transitions}

Table 1 summarizes Figure 3 in Scott (2004). ${ }^{2}$ It merges transitions between consecutive waves (1992-1994, 1994-1996, 1996-1998 and 1998-2000) in the HRS cohort born 1931-1941 of those who were salaried workers in 1992 (4,721 individuals; 14,163 transitions). The table distinguishes four labour market states (full-time work, partial retirement, phased retirement and full retirement) and combines data on number of hours worked and self-reported labour force status. ${ }^{3}$

The most common transition to a different labour market state is from full-time work to full-time retirement (2,686 transitions). Almost 38\% of all full-time workers are fully retired in the next wave. Almost $49 \%$ are still working full-time. The others enter partial or phased retirement. Of full-time workers who have stopped working full-time 2 years later, almost one of every ten stay with the same employer with reduced work effort (phased retirement), and almost two in ten change to another job (partial retirement). The other seven have gone into full-time retirement.

Workers typically do not stay long in partial or phased retirement. Only about one in every four workers observed in gradual retirement was still in gradual retirement 2 years later. Surprisingly, many of them went back to fulltime work, particularly if they had been in phased retirement (a 38\% transition rate). This makes the number of transitions from phased retirement

2 Other studies, such as Gustman and Steinmeier (2000), have shown similar transition rates, but usually for the earlier data only and with different labour market state definitions and samples.

3 Transitions from partial retirement or full retirement into phased retirement are not possible by construction. 
to full-time work larger than the number of transitions from phased retirement to full-time retirement. Scott (2004) provides no explanation for this unexpectedly large number of transitions back into full-time work. Similarly, we find many transitions from full-time retirement to gradual retirement or full-time work. Almost one in every three fully retired workers is no longer fully retired 2 years later. Of those who returned to work, more than a third worked fewer hours than before they retired, and are thus categorized as partially retired. Measurement error might explain part of the large number of transitions, but other research suggests that many of these "reverse transitions" are real. Maestas (2007) reports that slightly less than half of all workers follow a traditional retirement pattern without "reverse retirement."

All in all, the transition matrix in Table 1 illustrates the substantial mobility in the labour market for older workers in the US. In particular, retirement is not at all an absorbing state (in the sense that people who are once retired never return to work), and gradual retirement is usually not held for a long time, with many exits not only to full retirement but also back to full-time work. In Sect. 5 we will compare this with transition patterns in European countries.

\subsection{Sequences}

Sequences refer to particular retirement pathways, summarizing behaviour over a larger part of the life cycle. Three types of sequences can be distinguished. The first is an instantaneous exit from career employment into retirement, without gradual retirement. The second is a three-step sequence: career job employment - gradual retirement (partial or phased) - full retirement. The third category consists of all sequences that are non-monotonic, in the sense that they include transitions from gradual retirement to full-time work or from full retirement to gradual retirement (or both).

(Gustman and Steinmeier, 2000, Table 7) presented the sequences over the 6 years spanned by the first four waves of the HRS (1992-1998; cohort born 1931-1941). ${ }^{4}$ Four self-reported labour market states are distinguished: fulltime work, full retirement, gradual retirement and "not available." 5 These sequences are incomplete, in the sense that many respondents had not yet retired in 1998, explaining why $24.7 \%$ were continuously in full-time employment over the four waves. On the other hand, $8.0 \%$ were completely retired in all four waves. Partial retirement occurred at least once in about $22 \%$ of

4 Blau (1994) presented an overview of sequences in the older RHS cohort, but these are difficult to compare with those of Gustman and Steinmeier since the HRS cohort is observed at a younger age.

5 This includes those who refused to answer or answered "don't know" to the question on labour market status, proxy interviews for respondents who were not able to answer the questions, and respondents who dropped out of the survey. 
all sequences. In $8.9 \%$ of all sequences, the transition pattern was monotonic without partial retirement, with one transition from full-time work to fulltime retirement. The results also confirm the importance of reverse transitions: in about $14 \%$ of all sequences, a "reverse transition" took place, from full to partial retirement or from full- or partial retirement to full-time work.

\subsection{Durations}

Gustman and Steinmeier (1984a, 2000) found estimates of the average duration in gradual retirement of 2.55 years in the HRS and 2.76 years in the older RHS data. In contrast, Sueyoshi (1989) estimated a much longer average duration using the RHS, using a different definition of gradual retirement. (Sueyoshi, 1989, Table 2) found that in the RHS, direct retirees left full employment at an average age of 64.8 years. Gradual retirees went into gradual retirement at an average age of 64.7, and then fully withdrew from the labour market at age 69.8 (on average), much later than the normal retirement age. This suggests that gradual retirement induces many workers to remain in the labour market for about five more years. For the OECD as a whole, Reday-Mulvey and Delsen (1996) also reported that the period of gradual retirement typically lasts about 5 years.

Depending on when it starts and on its duration, gradual retirement may extend employment beyond the normal retirement age. (Scott, 2004, Table 10) addressed the same issue in a different way. He found that (keeping age and other variables constant) phased retirees are less likely to leave the labour force than full-time workers, although the difference is significant only at the $11 \%$ level.

\subsection{Correlates of Gradual Retirement}

Several studies have analysed how preferences for phased or partial retirement in the US vary with background variables. Gustman and Steinmeier (1984b), Honig and Hanoch (1985) and Sueyoshi (1989) used RHS data for this analysis. Here, we focus on three studies that have used the more recent data from the HRS.

Quinn (1996) studied transitions between the 1992 and 1994 waves of the HRS. He considered full-time workers in 1992, and estimated a logit model for holding a bridge job in 1994 . He found that transitions to a bridge job are significantly more likely for workers aged 63-65 and for construction workers, and less likely for the self-employed, for those with the highest education level, for home-owners, and for those who have children living with them. He found no independent effect of health on the probability to get a bridge job, but he did find a smaller probability to enter a bridge job for employees who would lose their health insurance and for employees with an employer- 
provided pension plan (irrespective of whether or not they were of eligible age). Both findings are in line with what one would expect, since losing health insurance or the opportunity to build up an occupational pension reduces the attractiveness of moving to another (bridge) job.

Ekerdt et al. (1996) analysed retirement plans in the HRS 1992, distinguishing five categories (stop working altogether, reduce effort, change job, never stop, or having no plans) and using multinomial logit analysis. They found that women are less likely to take gradual retirement than men. The tendency to reduce hours rather than change jobs increases with age. Both reducing hours and changing jobs are more prevalent for the higher than for the lower education levels. The self-employed are more likely to reduce hours, in line with the notion that they face fewer market restrictions. Entitlement to a private pension increases the tendency to stop working altogether, at the cost of all other alternatives. Being married also increases the odds to stop working altogether.

Kim and DeVaney (2005) explored the transition from full-time work in 1992 to full-time work, gradual retirement or complete retirement in 2000. They found that the self-employed have a higher probability of gradual retirement, probably because of more flexibility in determining their own working hours. Unlike other studies, they did find a health effect: those with more chronic conditions are more likely to reduce hours. The likelihood of gradual retirement also rose with age and education. They found that DB pension entitlement and investment assets increase the probability of full retirement, but do not change the odds of gradual retirement versus full-time work. They concluded that retirement decisions are sensitive to financial incentives (like pension plans), which creates scope for public policy.

The findings that DB pensions make partial retirement less likely and that the self-employed are more likely to take phased retirement are in line with the earlier studies based upon the RHS. These findings illustrate the importance of institutional restrictions on combining a DB-pension receipt with continued work, and employer-imposed restrictions on working part-time.

\section{GRADUAL RETIREMENT IN EUROPE}

Several studies have provided overviews of partial retirement arrangements in Europe. Delsen (1996) is an early example. Describing policies in Denmark, Finland and Sweden, he concluded that only the Swedish programme could be called successful, in the sense of reducing the number of early withdrawals from the labour force. The Swedish partial-pension scheme was introduced in 1976, with a generous partial pension in combination with work for workers of 60 years and older. Several substantial changes in generosity were introduced in later years. Both the government and the employers supported the Swedish scheme, which was seen as a means of reducing labour costs dur- 
ing an economic recession. The crucial condition to make it a success was an adequate supply of part-time jobs. This condition was met, since Swedish firms were already familiar with organizing part-time employment and willing to share the responsibility of society to guarantee employment to older workers. An important attraction for employees is that the Swedish scheme counts the partial pension as pensionable income so that taking up a partial pension does not affect the old age pension (Wadensjö 2006, p. 31). The Swedish system was abolished in 2001, but a new scheme was introduced in 2003. The current system entitles workers older than 61 to reduce working hours by as much as $50 \%$, and to draw $100,75,50$ or $25 \%$ of the full pension (Belloni et al. 2006). Wadensjö (2006) studied the Swedish partial-pension scheme in detail. He exploited changes in the system to analyse its consequences for participation and labour supply. Although he did not estimate any econometric models but merely looked at the raw data, he concluded that the positive effect of increased participation clearly outweighs the negative effect of fulltime workers reducing their hours to part-time, so that the total effect of the partial-pension programme on labour supply is positive.

The Danish system introduced in 1987 applies to workers between the ages of 60 and 65 satisfying some conditions concerning their past participation (and, for the self-employed, profits; see Belloni et al. 2006). They can reduce their working hours and receive a partial pension proportional to the reduction in working time. Although the Danish scheme was modelled after the Swedish model, it was much less successful. Delsen (1996) argued that this was due mainly to the unfavourable labour market at the time of its introduction - a severe recession, with pressure on older workers to take full rather than phased retirement.

A similar argument explains the lack of success in Finland, where a partial pension scheme was introduced in 1987. The current rules allow workers between the ages of 58 and 67 to reduce their working hours to $16-28 \mathrm{~h}$ per week and replace $50 \%$ of foregone earnings by a partial pension (Belloni et al. 2006). Other reasons why the Finnish system was not successful were that the Finnish system is more complicated and part-time jobs were hard to find (Delsen 1996).

Belloni et al. (2006) also describes gradual retirement arrangements in Spain (existing since the 1960s), France (since 1988) and Germany (since 1992). These systems all allow workers of age 60 or 61 and older to reduce working time and receive a corresponding partial pension (conditional on having contributed a long enough time to the social security system). According to Reday-Mulvey (2000), it seems that the programmes in France and Germany were successful as a substitute for very generous schemes of early complete retirement. She emphasizes the key role of training older workers, which is commonly done in Sweden and in the larger companies in France. 
The countries discussed above are the only countries that have an explicit arrangement for combining part-time work with a part-time pension, but Reday-Mulvey (2000) found that most EU countries have introduced schemes that make it possible to combine work and pension receipt. The situation in the Netherlands is rather complicated, due to the variety of occupational pension schemes with their own rules. (Belloni et al., 2006, p.12) stated that "some of these schemes allow workers at the end of their careers to reduce their working hours and receive a partial pension." Delsen (1996) also described some tendencies toward partial retirement opportunities in the Netherlands, which he identified as a promising way to cope with the problem of ageing, raising the effective retirement age and easing future fiscal problems.

Morris and Mallier (2003) analysed the importance of part-time work and self-employment among older age groups for the EU-15. They found that in many countries, part-time work among men is much more prevalent at ages 60-64 and 65-69 than at earlier ages, although there is huge variation across countries. In particular, in the Northern part of Europe, part-time work among men is common, while in the Southern European countries, selfemployment is more prevalent.

\subsection{Part-time Work in Europe}

Whether employees in European countries prefer to reduce their work effort as they age can be inferred from comparing part-time employment rates among younger and older workers. Although part-time workers are not always in gradual retirement, this will still give an impression of how many older workers reduce their working hours toward the end of their career. The data used here were drawn from the European Community Household Panel, a panel dataset following individuals aged 16 and over from 1994 to $2001 .^{7}$

Table 2 presents the shares of part-time workers among all workers (working either part-time or full-time) for men and women in two age categories, 35-50 and 51-65, and for the years 1994, 1998 and 2001. Part-time status is determined by the subjective question "Did you work full-time or part-time?" In almost all cases, part-time employment is more prevalent in the older age category than in the younger category, suggesting that workers reduce their work effort later in life. In many countries, the proportions of part-time workers decline over time, particularly for males. We therefore find no evidence that gradual retirement becomes increasingly prevalent over this time period. There is huge variation in the prevalence of part-time work across countries, for both sexes and in both age groups. In the Netherlands, part-time work

6 On p. 22, Belloni et al. (2006) have replaced "some" by "many".

7 See Peracchi (2002) for more information on ECHP. 
TABLE 2 - PART-TIME WORK OF TOTAL EMPLOYMENT (\%)

\begin{tabular}{|c|c|c|c|c|c|c|}
\hline & \multicolumn{2}{|l|}{1994} & \multicolumn{2}{|l|}{1998} & \multicolumn{2}{|l|}{2001} \\
\hline & $35-50$ & $51-65$ & $35-50$ & $51-65$ & $35-50$ & $51-65$ \\
\hline & \multicolumn{6}{|l|}{ Men } \\
\hline Germany & 2.1 & 7.3 & 2.3 & 8.6 & 2.8 & 2.8 \\
\hline Denmark & 2.5 & 6.8 & 2.4 & 8.0 & 2.1 & 4.8 \\
\hline Netherlands & 4.6 & 13.4 & 5.3 & 11.6 & 5.7 & 10.4 \\
\hline Belgium & 2.3 & 6.9 & 1.7 & 5.2 & 0.8 & $(5.1)$ \\
\hline France & 5.8 & 9.4 & 1.3 & (3.9) & 1.3 & 3.6 \\
\hline UK & 5.1 & 8.9 & 2.5 & 6.4 & 2.5 & 4.8 \\
\hline Ireland & 5.3 & 8.8 & 5.7 & 12.0 & 5.3 & 11.9 \\
\hline Italy & 5.9 & 10.4 & 2.1 & 5.7 & 1.6 & 4.1 \\
\hline Greece & 6.6 & 9.0 & 2.1 & 2.6 & 1.2 & 2.8 \\
\hline Spain & 3.7 & 6.5 & 1.9 & 3.4 & 2.2 & 2.9 \\
\hline Portugal & 3.0 & 9.0 & 1.3 & 6.8 & 1.1 & 5.3 \\
\hline Austria & 0.7 & 3.5 & 1.8 & $(4.2)$ & 1.9 & 5.8 \\
\hline Finland & 3.3 & 8.5 & 3.2 & 9.0 & 3.1 & 7.5 \\
\hline \multirow[t]{2}{*}{ Sweden } & 2.3 & 6.4 & 1.7 & 6.2 & 1.5 & 4.6 \\
\hline & \multicolumn{6}{|c|}{ Women } \\
\hline Germany & 37.9 & 39.7 & 32.5 & 37.1 & 30.0 & 33.4 \\
\hline Denmark & 19.4 & 37.3 & 16.9 & 28.6 & 14.7 & 28.6 \\
\hline Netherlands & 63.8 & 68.3 & 63.2 & 64 & 61.6 & 60.4 \\
\hline Belgium & 28.6 & 32.3 & 30.8 & 29.4 & 32.6 & 35.1 \\
\hline France & 23.3 & 27.8 & 17.0 & 19.7 & 14.3 & 20.3 \\
\hline UK & 43.7 & 45.3 & 15.8 & 23.7 & 14.0 & 26.0 \\
\hline Ireland & 46.4 & 42.6 & 44.6 & 55.5 & 40.3 & 46.3 \\
\hline Italy & 26.2 & 29.9 & 12.4 & 11.1 & 13.3 & 10.6 \\
\hline Greece & 17.0 & 21.6 & 9.6 & 18.9 & 7.6 & 17.4 \\
\hline Spain & 21.5 & 23.4 & 16.2 & 24.1 & 19.7 & 22.4 \\
\hline Portugal & 12.5 & 25.6 & 11.7 & 24.8 & 10.8 & 25.2 \\
\hline Austria & 27.6 & (25.9) & 29.3 & 31.5 & 30.6 & 27.5 \\
\hline Finland & 8.6 & 12.8 & 9.1 & 15.7 & 8.0 & 17.3 \\
\hline Sweden & 15.9 & 22.0 & 16.8 & 20.2 & 13.0 & 19.4 \\
\hline
\end{tabular}

Notes: 1. Based upon self-assessed labour market status. 2. For Germany, Sweden and the UK, the presented numbers are from national surveys converted into the ECHP format. 3. The numbers in italics refer to the closest survey year that data is available: for Austria it is 1995, for Finland it is 1996, and for Sweden it is 1997 . The numbers in parentheses indicate that data are missing for various ages within the age category. 4 . The sample is weighted.

among older men and among women in both age groups is much higher than in most other countries.

Table 3 defines part-time as working $1-34 \mathrm{~h}$ per week. Again, there is no clear time trend. In comparison to Table 2, the preference for reduced labour in the late working life is even more pronounced, particularly among men. Table 3 also contains the US, with data drawn from the Panel Study of Income Dynamics (PSID) (Since the PSID has no self-assessed part-time status, the US could not be included in Table 2). It shows that part-time work among women is less common in the US than in Europe for both age groups. The figures for men are comparable to those in Europe. 
TABLE 3 - WORKING 1-34 h PER WEEK (\%)

\begin{tabular}{|c|c|c|c|c|c|c|}
\hline & \multicolumn{2}{|l|}{1994} & \multicolumn{2}{|l|}{1998} & \multicolumn{2}{|l|}{2001} \\
\hline & $35-50$ & $51-65$ & $35-50$ & $51-65$ & $35-50$ & $51-65$ \\
\hline & \multicolumn{6}{|l|}{ Men } \\
\hline Germany & 2.6 & 6.3 & 4.6 & 9.8 & 3.7 & 6.7 \\
\hline Denmark & 3.1 & 6.7 & 2.7 & 8.6 & 3.4 & 5.8 \\
\hline Netherlands & 7.3 & 14.0 & 10.0 & 17.5 & 11.6 & 17.0 \\
\hline Belgium & 3.7 & 6.6 & 3.5 & 10.9 & 3.7 & (8.7) \\
\hline France & 6.3 & 9.3 & 4.3 & $(6.8)$ & 4.8 & 6.3 \\
\hline UK & 3.5 & 10.5 & 3.7 & 9.6 & 4.3 & 7.7 \\
\hline Ireland & 7.1 & 11.0 & 9.3 & 19.2 & 9.4 & 18.9 \\
\hline Italy & 6.6 & 10.4 & 5.1 & 11.0 & 4.9 & 8.5 \\
\hline Greece & 8.4 & 10.2 & 7.2 & 11.5 & 6.8 & 9.4 \\
\hline Spain & 5.3 & 7.3 & 4.2 & 4.3 & 4.4 & 4.6 \\
\hline Portugal & 3.8 & 9.4 & 1.9 & 7.6 & 1.6 & 7.1 \\
\hline Austria & 2.2 & 3.0 & 2.8 & (3.7) & 2.6 & 7.2 \\
\hline Finland & 6.2 & 12.1 & 6.9 & 12.8 & 4.5 & 12.1 \\
\hline Sweden & 3.5 & 10.8 & 3.4 & 9.0 & 3.6 & 7.2 \\
\hline \multirow[t]{2}{*}{ US } & 5.6 & 12.9 & 4.8 & 8.9 & 4.1 & 8.4 \\
\hline & \multicolumn{6}{|c|}{ Women } \\
\hline Germany & 42.2 & 45.0 & 44.1 & 50.3 & 44.1 & 46.7 \\
\hline Denmark & 30.4 & 50.6 & 33.1 & 40.8 & 30.5 & 46.1 \\
\hline NL & 75.1 & 75.5 & 77.9 & 75.4 & 76.0 & 79.1 \\
\hline Belgium & 36.3 & 39.3 & 41.6 & 36.9 & 45.5 & 47.5 \\
\hline France & 30.1 & 30.8 & 32.3 & 31.1 & 29.2 & 29.7 \\
\hline UK & 50.2 & 58.5 & 48.1 & 54.2 & 44.7 & 56.5 \\
\hline Ireland & 54.5 & 49.4 & 57.0 & 69.3 & 57.2 & 60.9 \\
\hline Italy & 30.0 & 35.6 & 31.6 & 33.1 & 32.1 & 34.9 \\
\hline Greece & 22.9 & 31.7 & 23.0 & 37.6 & 21.0 & 39.3 \\
\hline Spain & 27.9 & 29.8 & 23.8 & 34.0 & 29.1 & 32.4 \\
\hline Portugal & 16.4 & 32.2 & 16.4 & 32.8 & 15.5 & 32.9 \\
\hline Austria & 38.8 & $(32.9)$ & 41.0 & 35.6 & 41.0 & 35.5 \\
\hline Finland & 15.6 & 14.9 & 16.7 & 19.5 & 16.5 & 21.0 \\
\hline Sweden & 33.5 & 38.3 & 37.2 & 36.8 & 33.1 & 33.9 \\
\hline US & 18.6 & 25.8 & 15.4 & 18.7 & 14.5 & 19.8 \\
\hline
\end{tabular}

Notes: 1. For Germany, Sweden and the UK the presented numbers are from national surveys converted into the ECHP format. 2. The ECHP sample is weighted. 3. The US numbers are from the PSID. The sample is not weighted. 4. The numbers in italic refer to the closest survey year that data is available: for Austria it is 1995, for Finland 1996, for Sweden 1997, and for the US 2000. The numbers in parentheses indicate that data are missing for various ages within the age category. 
TABLE 4 - TWO-YEAR TRANSITION RATES 1994-2000 (\%)

\begin{tabular}{|c|c|c|c|c|c|c|c|c|c|}
\hline & $\mathrm{FF}$ & FP & $\mathrm{FO}$ & $\mathrm{PF}$ & PP & $\mathrm{PO}$ & $\mathrm{OF}$ & $\mathrm{OP}$ & $\mathrm{OO}$ \\
\hline & \multicolumn{9}{|c|}{$35-50$ Years Old } \\
\hline Austria & 94.2 & 3.1 & 2.8 & 14.8 & 76.9 & 8.3 & 8.4 & 13.4 & 78.2 \\
\hline Finland & 92.7 & 4.1 & 3.2 & 36.8 & 45.2 & 18.0 & 26.6 & 10.7 & 62.8 \\
\hline Denmark & 92.8 & 4.3 & 2.9 & 21.3 & 69.4 & 9.3 & 24.8 & 13.9 & 61.3 \\
\hline Netherlands & 91.8 & 5.8 & 2.3 & 9.6 & 83.8 & 6.7 & 5.8 & 16.7 & 77.5 \\
\hline Belgium & 91.9 & 5.0 & 3.1 & 17.1 & 75.4 & 7.5 & 5.5 & 6.3 & 88.2 \\
\hline France & 91.9 & 3.7 & 4.5 & 19.0 & 66.5 & 14.5 & 11.9 & 6.9 & 81.2 \\
\hline Ireland & 90.1 & 5.6 & 4.3 & 16.5 & 68.2 & 15.3 & 8.3 & 17.3 & 74.4 \\
\hline Italy & 92.2 & 3.6 & 4.2 & 23.8 & 66.0 & 10.1 & 6.7 & 4.6 & 88.7 \\
\hline Greece & 88.8 & 5.1 & 6.0 & 32.0 & 52.3 & 15.6 & 11.9 & 5.6 & 82.5 \\
\hline Spain & 89.2 & 3.8 & 7.0 & 37.3 & 40.3 & 22.4 & 13.0 & 4.8 & 82.2 \\
\hline Portugal & 92.0 & 2.9 & 5.2 & 37.2 & 52.4 & 10.3 & 17.6 & 8.6 & 73.9 \\
\hline Germany & 91.4 & 3.7 & 4.9 & 18.2 & 73.6 & 8.2 & 15.9 & 13.4 & 70.7 \\
\hline UK & 91.4 & 4.7 & 3.9 & 18.2 & 72.2 & 9.6 & 10.5 & 12.9 & 76.6 \\
\hline \multirow[t]{2}{*}{ US } & 94.6 & 3.5 & 1.8 & 52.2 & 37.4 & 10.2 & 19.6 & 11.8 & 68.5 \\
\hline & \multicolumn{9}{|c|}{ 51-65 Years Old } \\
\hline Austria & 71.2 & 2.2 & 26.6 & 13.9 & 56.8 & 29.4 & 0.9 & 1.2 & 97.9 \\
\hline Finland & 75.7 & 7.4 & 17.0 & 14.2 & 49.1 & 36.7 & 2.0 & 2.3 & 95.7 \\
\hline Denmark & 79.4 & 6.3 & 14.5 & 9.5 & 60.3 & 30.2 & 2.7 & 3.5 & 93.7 \\
\hline Netherlands & 74.9 & 9.7 & 15.4 & 7.0 & 71.1 & 21.9 & 1.0 & 2.6 & 96.4 \\
\hline Belgium & 73.9 & 6.0 & 20.2 & 9.7 & 54.8 & 35.5 & 0.4 & 0.9 & 98.7 \\
\hline France & 74.1 & 4.4 & 21.5 & 11.2 & 51.0 & 37.7 & 1.2 & 0.9 & 97.9 \\
\hline Ireland & 78.5 & 8.9 & 12.6 & 19.1 & 57.2 & 23.7 & 1.8 & 6.6 & 91.6 \\
\hline Italy & 72.9 & 4.1 & 22.9 & 14.7 & 50.9 & 34.4 & 1.4 & 1.0 & 97.7 \\
\hline Greece & 70.1 & 8.3 & 21.6 & 29.3 & 36.2 & 34.5 & 2.9 & 2.3 & 94.8 \\
\hline Spain & 74.3 & 3.7 & 22.0 & 21.8 & 40.9 & 37.3 & 2.4 & 1.7 & 95.9 \\
\hline Portugal & 76.6 & 7.7 & 15.7 & 20.2 & 49.6 & 30.2 & 3.9 & 4.4 & 91.6 \\
\hline Germany & 74.5 & 4.8 & 20.7 & 10.4 & 61.1 & 28.4 & 1.7 & 2.4 & 95.9 \\
\hline UK & 78.5 & 6.6 & 14.9 & 7.9 & 66.4 & 25.8 & 1.9 & 3.0 & 95.0 \\
\hline US & 85.4 & 6.5 & 9.4 & 23.0 & 54.5 & 22.4 & 4.0 & 3.5 & 92.4 \\
\hline
\end{tabular}

Notes: 1. 'F' refers to full-time work, 'P' to part-time work, and 'O' to other (not working). In the PSID the 'other' category refers to "did not work for money now or did not work at all" and in the ECHP it refers to "unemployed, discouraged worker, or economically inactive". 2. Fulltime and part-time work definitions are based on actual work hours. Part-time work is $1-34 \mathrm{~h}$ of work per week. 3. The table is based on survey units which are traceable through all four waves. 4. The numbers for Austria and Finland are over the last three biennial waves, 1996-2000, due to missing data for 1994. For Germany and the UK the numbers are from national surveys (GSOEP and BHPS) converted to the ECHP format. 5. The ECHP sample is weighted. 
In the previous section, we discussed the remarkably large number of reverse retirement transitions in the US, from gradual retirement back to full-time work, or from full retirement back to full-time or part-time work. Although we cannot use Scott's labour force status definitions for Europe to compare this type of mobility in Europe and the US, comparing ECHP and PSID as in Table 3 gives the possibility for a comparison of mobility based upon working hours only. Average 2-year transition rates for 19942000 between full-time work, part-time work and no work, the same classification as in Table 1, are presented in Table 4. The table reveals many differences across countries. The Netherlands stands out as the country where part-time work is most persistent, among both the younger and the older age group. In general, for the age group 51-65, reverse transition rates for the US are among the largest, although not completely out of line with the European transition rates. This suggests that reverse transitions also deserve more attention in many European countries. For example, it would be worthwhile to investigate the extent to which such transitions are anticipated, or are a reaction to an unexpectedly low replacement rate (cf. Maestas 2007).

\section{GRADUAL RETIREMENT IN THE NETHERLANDS}

Figures 1-3 illustrate the potential relevance of gradual retirement in the Netherlands. Figure 1 shows the development over the period 1987 until 2006 of employment rates for men and women, for the age groups 35-50 and 51-65 (where only people who work $12 \mathrm{~h}$ per week or more are counted as employed). The employment rate among prime age men has been rather stable at around $90 \%$. The employment rate of the older part of the male labour force has increased substantially around the turn of the century and has stabilized at about $60 \%$ since then. For prime age women, employment rates have increased substantially until about 2001 and seem to have stabilized since, while the employment rate among women in the age group 51-65 continued to increase. Both figures suggest that a policy of increasing employment has more promise for the older part of the labour force than for the prime age groups.

Figure 2 presents the fraction of part-time workers (working 1-34 hours) among all workers. For men aged 51-65, this percentage has increased a few percentage points around 2000, whereas it has remained stable for men aged 35-50. The larger rates for older men suggest that a substantial number of men reduce their hours when approaching retirement age. For women, parttime work is hardly more common among the older than among the younger ages. The increasing rates among younger women may be related to the increase in participation (Figure 1) - much of this is in the form of part-time work. 

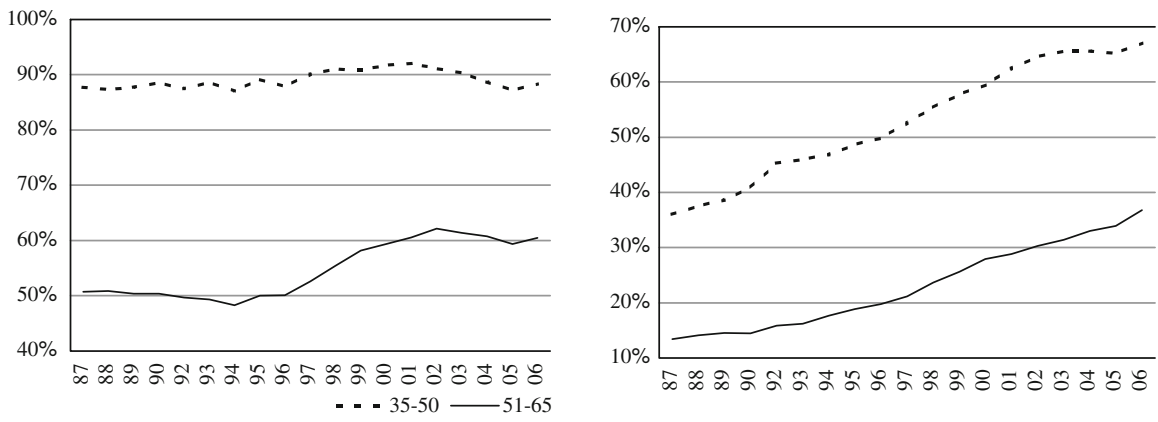

Figure 1 - Employment Rates. Source: Enquete Beroepsbevolking, Statistics Netherlands; 80,000 to 120,000 observations for each cross section. The variable is not available for the year 1991 . Observations are weighted with cross sectional weights. The percentages represent the share of working population in the total of those working, unemployed or not belonging to the labour force

It is interesting to compare Figures 2 with Figure 3, presenting the percentage that would want to work part-time. Particularly for men aged 51-65, this percentage has increased substantially over the past decade and exceeds by far the percentage of men who actually work $1-34 \mathrm{~h}$. This suggests that many older men would like to reduce their work hours and take some form of gradual retirement, but for some reason are not able to do this.

This discussion makes clear that both limitations imposed by employers or institutions and preferences of the workers are important determinants of gradual retirement. In the remainder of this section, we consider both.
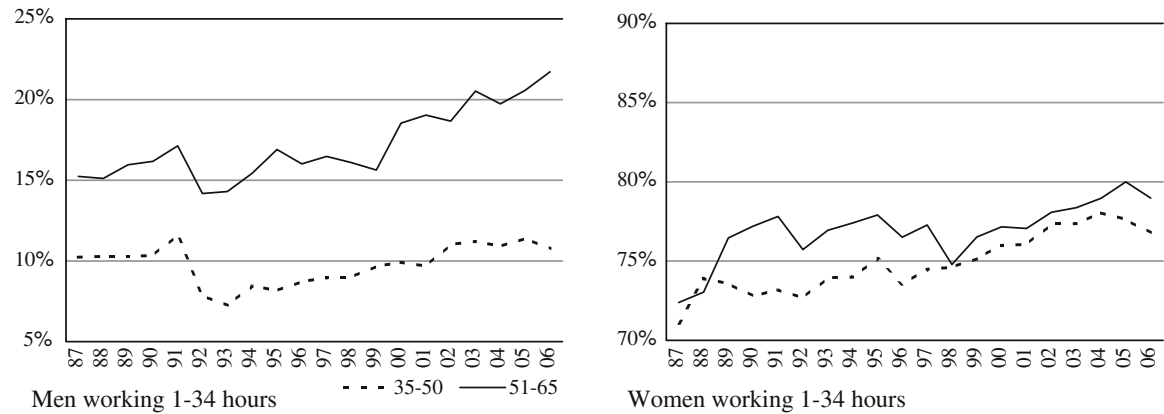

Figure 2 - Employees working 1-34h. Source: Enquete Beroepsbevolking, Statistics Netherlands; about 60,000 obervations for each cross section. Observations are weighted with cross sectional weights. The percentages represent the share of those working $1-34 \mathrm{~h}$ in those working any number of hours 


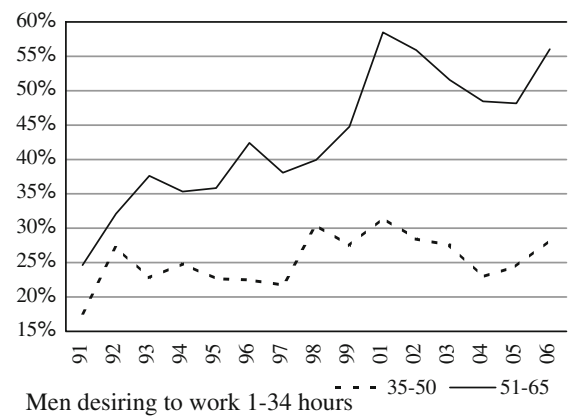

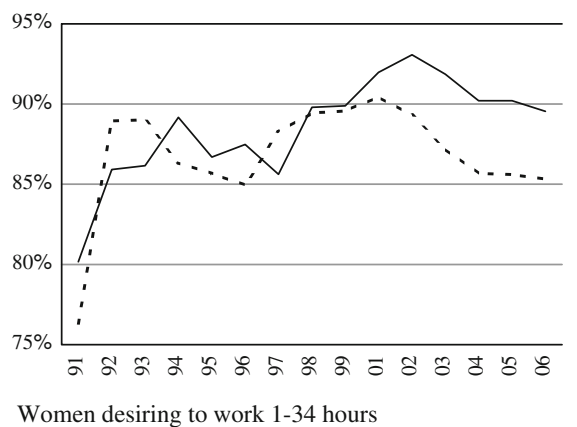

Figure 3 - Employees desiring to work 1-34h. Source: Enquete Beroepsbevolking, Statistics Netherlands; 5,000 to 9,000 observations for each cross section. Observations are weighted with cross sectional weights. The variable is not available for 2000 and before 1991. The percentages represent the share of those who desire to work $1-34 \mathrm{~h}$ in those who desire to work any number of hours

\subsection{Legal Issues}

Ceelen (2007) considers legal issues that restrict access to gradual retirement. The general conclusion of his analysis: although no major legal obstacles seem to exist, some fine-tuning is still required, particularly concerning taxation. Specific issues arise if gradual retirement is combined with another taxfavoured arrangement, the so-called life-course scheme. Ceelen recommended more transparency of the tax treatment in such cases. Other issues arise with working after age 65 . For example, not all pension funds allow for accumulating pension entitlements after age 65. Moreover, the obligation to pay wages for two years if the employee becomes ill may be an impediment for employers. Thus there is some scope for specific policies for workers aged 65 and older.

\subsection{Employer Attitudes}

In March 2007, we fielded a survey focusing on opportunities provided by and restrictions imposed on phased retirement. Employees older than 25 years of age in the CentERpanel (a representative panel of the Dutch adult population, see www.centerdata.nl) were asked how they perceived the possibilities for phased retirement at their current employer. The sample has 815 observations. The first question in the module on phased retirement was as follows:

"Does your employer offer you the possibility of part-time retirement? (Part-time retirement means that you retire part of your working week 
TABLE 5 - ESTIMATION RESULTS

\begin{tabular}{|c|c|c|c|c|}
\hline \multirow[t]{3}{*}{ Explanatory variable } & \multicolumn{2}{|l|}{ LOGIT } & \multicolumn{2}{|l|}{ OLS } \\
\hline & \multicolumn{2}{|c|}{ Access to phased retirement } & \multicolumn{2}{|c|}{ Age of phased retirement } \\
\hline & Coefficient & $t$-value & Coefficient & $t$-value \\
\hline Men & -0.13 & $(-0.60)$ & 0.47 & (1.33) \\
\hline Children 1+ & 0.20 & $(1.00)$ & 0.90 & $(2.26)$ \\
\hline Partner & 0.14 & $(0.63)$ & 0.40 & $(0.81)$ \\
\hline Age $35-44$ & -0.18 & $(-0.73)$ & 0.93 & $(1.85)$ \\
\hline Age $45-54$ & 0.16 & $(0.68)$ & 1.72 & (3.41) \\
\hline Age $55+$ & -0.07 & $(-0.25)$ & 1.99 & (3.49) \\
\hline Education mid & 0.02 & $(0.07)$ & 0.50 & $(0.96)$ \\
\hline Education high & 0.19 & $(0.77)$ & 0.59 & $(1.01)$ \\
\hline Income mid & 0.37 & $(1.30)$ & -0.02 & $(-0.03)$ \\
\hline Income high & 0.48 & $(1.33)$ & -0.41 & $(-0.61)$ \\
\hline Region west & -0.35 & $(-1.27)$ & -1.01 & $(-2.32)$ \\
\hline Region north & -0.12 & $(-0.36)$ & -0.54 & $(-0.87)$ \\
\hline Region east & -0.08 & $(-0.28)$ & -0.38 & $(-0.91)$ \\
\hline Region south & 0.00 & $(0.01)$ & -1.18 & $(-2.40)$ \\
\hline Sector comm. service & -0.28 & $(-1.20)$ & 0.19 & $(0.39)$ \\
\hline Sector publ. service & 0.73 & (3.10) & -0.12 & $(-0.25)$ \\
\hline Intercept & -0.68 & $(-1.44)$ & 58.57 & $(57.68)$ \\
\hline
\end{tabular}

Notes: 1. Logit estimates: Employees ages 25-65, CentER panel, 815 observations. Dependent variable: dummy for perceived access to phased retirement with current employer. 2. OLS estimates: Employees ages 25-65, CentER panel, respondents with access to phased retirement at current employer; 393 observations. Dependent variable: perceived age at which phased retirement can start.

but keep working the other part-for example, from age 62 until age 65.)"

Almost half of the respondents $(47.3 \%)$ of the sample answered affirmatively. This is much higher than in Van Soest et al. (2006), who used data from 2004 and also included retired former employees and found that $34.2 \%$ responded affirmatively. The difference cannot be explained solely by the lower rate among retirees (who were asked about their last job as an employee) and suggests that perceived access to phased retirement has increased, which corresponds to the fact that large pension funds have created transparent opportunities for partial pensions.

The left hand panel of Table 5 presents the estimates of a logit model explaining the dummy variable that has value 1 for respondents who think they have access to phased retirement, and 0 for those who do not think they have access. A positive coefficient on an explanatory variable thus means 
that an increase in this variable makes access to phased retirement more likely (although, since we only measure the employee's perception, it might also mean that the respondent has different information). Phased retirement opportunities are significantly more common in the public sector than in manufacturing or commercial services. The difference in the access probability for an average worker in the public sector and the manufacturing sector is about $18 \%$-points, keeping other variables constant. Other variables are not significant, although the income variables are jointly significant at the $10 \%$ level, suggesting that access to phased retirement is more common among the higher income groups. ${ }^{8}$

Employees who answered the question on access to phased retirement affirmatively then got a follow-up question on the earliest age at which they thought they could reduce their hours of work. The distribution of the answers is concentrated at ages 60 and 62 , with about $30 \%$ and $35 \%$ of the (393) observations, respectively. The overall mean is 60.3 years of age. The right hand panel of Table 5 presents the results of a linear regression explaining this earliest age of phased retirement from background variables (not correcting for selective access). Several variables are significant. The expected age rises with the presence of children, which may reflect a selection effect - respondents with children might have chosen different types of jobs. The earliest phased retirement age also rises with the age of the respondent, suggesting that younger cohorts are less optimistic about early phased retirement. The highest age of phased retirement is reported in the three big cities. Finally, somewhat surprisingly, no differences across sectors were found. In general, it seems difficult to interpret these results, perhaps due to the selective nature of access to phased retirement or because variables proxy something else.

The respondents who reported not to have access to phased retirement were asked why they think their employer does not offer such opportunities. Each respondent was asked to assess the importance of six potential reasons, presented in Table 6, on a five-point scale (from 1: "does not apply" to 5: "the decisive argument"); Table 6 shows the frequency distribution of these rating. Reasons 4 (employer wants me to continue working full time) and 1 (parttime not attractive for my kind of work) appear to be the most important ones. The fact that reason 4 is rated more important than reasons 5 and 6 seems to confirm that older workers are seen as valuable, with useful experience and high productivity, but some words of caution are necessary: this is the employees' perception of their employer's considerations, and not directly the view of the employers.

8 Other job characteristics that might play a role are occupation (level) and firm size, but these are not available in the current data set. 
TABLE 6 - REASONS FOR NON-ACCESS TO PHASED RETIREMENT - FREQUENCY DISTRIBUTIONS

\begin{tabular}{llllrc}
\hline $\begin{array}{l}\text { 1. Does } \\
\text { not apply }\end{array}$ & $\begin{array}{l}\text { 2. Applies } \\
\text { perhaps }\end{array}$ & $\begin{array}{l}\text { 3. Probably } \\
\text { applies }\end{array}$ & $\begin{array}{l}\text { 4. Definitely } \\
\text { applies }\end{array}$ & $\begin{array}{l}\text { 5. Most } \\
\text { important } \\
\text { reason }\end{array}$ \\
\hline R1 & 38.9 & 15.1 & 15.3 & 21.8 & 8.7 \\
R2 & 46.6 & 13.7 & 17.6 & 12.6 & 9.2 \\
R3 & 38.4 & 24.1 & 24.7 & 7.4 & 5.1 \\
R4 & 31.9 & 17.3 & 21.5 & 18.6 & 10.5 \\
R5 & 54.2 & 18.5 & 17.1 & 6.7 & 3.3 \\
R6 & 35.8 & 20.4 & 25.8 & 12.5 & 5.2 \\
\hline
\end{tabular}

Notes: Employees ages 25-65, CentER panel, respondents without access to phased retirement at current employer; 423 observations Rows: Reasons for not offering gradual retirement: R1: Parttime work is not attractive for the type of work I do R2: My employer does not offer any parttime jobs R3: My pension fund does not allow for a partial pension R4: My employer prefers that people like me keep working full-time until normal retirement age R5: My employer prefers that people like me retire completely as early as possible R6: My employer thinks the cost of part-time workers relative to full-time workers is too high.

Table 7 presents ordered logit estimates explaining the rating of each of the six reasons separately. The difference between men and women is largest for the first reason: part-time work is not attractive for the type of work typically done by men. This seems in accordance with the fact that women often choose occupations where part-time work is more common and generally accepted. Men are also much more often in jobs where (at least in the worker's perception) employers want to keep them full-time until normal retirement age (reason 4).

The education patterns show that workers with an intermediate level of education differ considerably in their answers, while workers with high- and low levels of education are more similar. Workers with intermediate education are often skilled workers with vocational training in professions where part-time work is not common (reason 1). They also often think reason 3 is important: restrictions in the rules imposed by their pension funds. Perhaps this is because they often participate in (smaller) pension funds, where rules for phased retirement are not as generous or transparent as for large pension funds. For high-income workers, the argument that employers want to keep their workers full-time is relatively important (reason 4), but they also attach significantly more weight to reasons 1 and 3 , which both refer to the nature of their work.

The only significant difference across regions is that workers in the northern provinces more often have the impression that their employer wants to consign them to early retirement as soon as possible. There are many sig- 


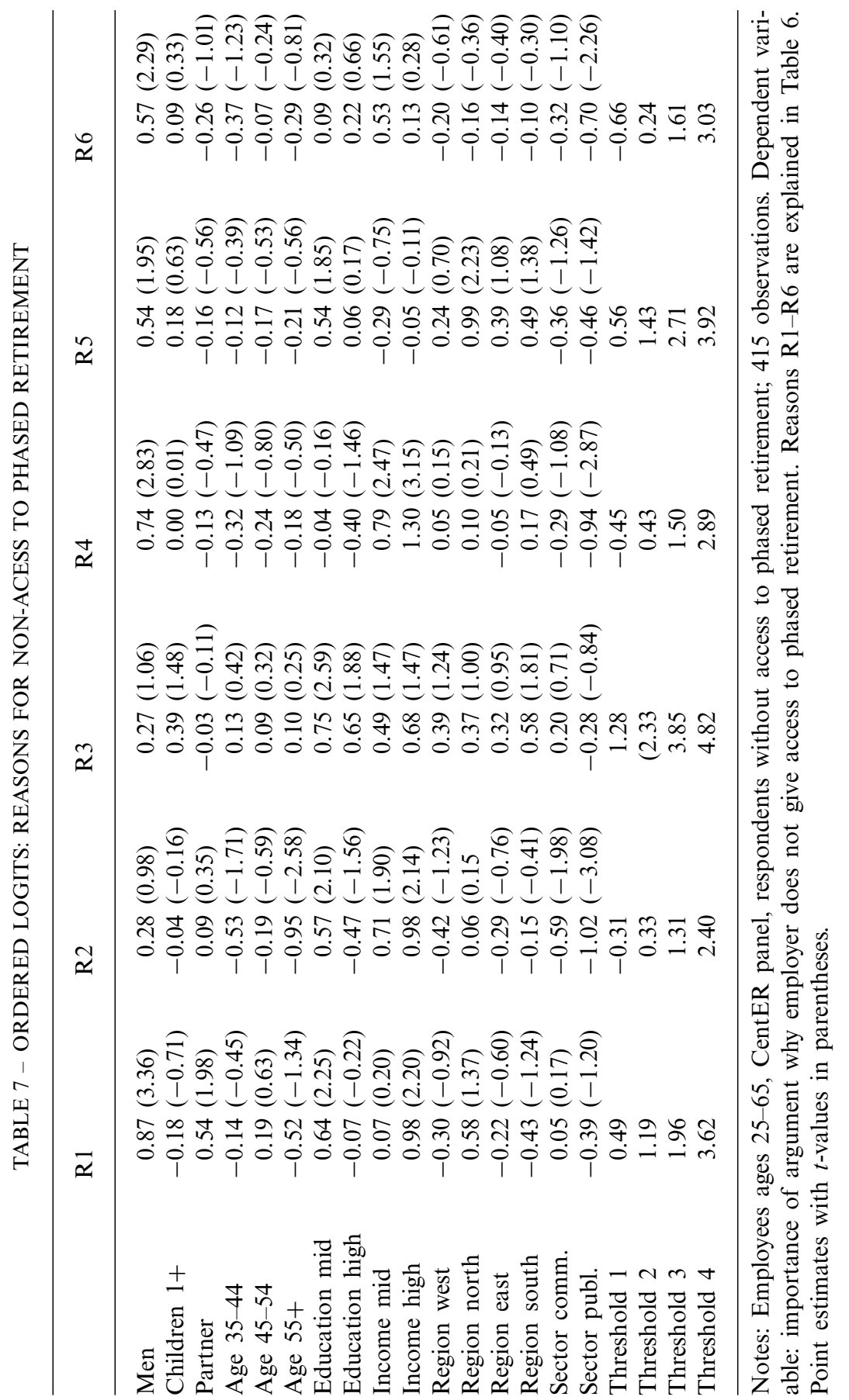


nificant differences across the three sectors. Several reasons are much less important in the public sector than in the manufacturing industry. The most important reason is that employers simply do not offer part-time jobs (reason 2) - part-time work is much more common in the public sector than elsewhere.

\subsection{Preferences for Gradual Retirement and Labour Supply}

Van Soest et al. (2006) used a stated-preference technique to estimate gradual retirement preferences of the Dutch. They presented hypothetical retirement scenarios to a sample of workers and former workers aged 25 and over, and asked them to rate each of these scenarios on a scale from one to ten. An example of such a scenario is as follows:

\begin{tabular}{lll}
\hline Until 65 & From 65 until 70 & 70 and over \\
\hline $\begin{array}{l}\text { Working } \\
\text { 38 h per }\end{array}$ & $\begin{array}{l}\text { Working } 23 \mathrm{~h} \text { per week, after-tax } \\
\text { income is } 100 \% \text { of earnings at }\end{array}$ & $\begin{array}{l}\text { Not working, net pension income is } \\
\text { week }\end{array}$ \\
age 65.
\end{tabular}

This scenario has gradual retirement from age 65 until age 70. An introductory text asked the respondent to assume that the employer fully cooperates, so that the scenario refers to phased rather than partial retirement. The replacement rates during phased retirement and after full retirement are randomized. Respondents rated eight scenarios, with and without gradual retirement and with varying replacement rates and (gradual) retirement ages.

The differences between the average ratings give a first impression of people's preferences. For example, the scenario presented above has an average rating of 4.0 , compared to 4.8 for the benchmark scenario - full-time work until age 65 and complete retirement thereafter with a $70 \%$ replacement rate. This suggests that people on average dislike working after age 65 , even part-time, in spite of the compensation in the form of a higher income after age 65. Higher average ratings are given for scenarios of gradual retirement centring at age 65 (gradual retirement at age 63; full retirement at age 67).

Van Soest et al. (2006) used these ratings to estimate an intertemporal model explaining retirement choices. Table 8 reproduces some of their results, giving the average probabilities that a hypothetical scenario is rated higher than the benchmark (no gradual retirement; full retirement at age 65 with replacement rate $70 \%$ ). The table shows that hardly anyone would be interested in working full-time until age 70 , even if the replacement rate were $100 \%$. Early retirement, on the other hand, is much more attractive, partic- 
TABLE 8 - SIMULATED CHOICE PROBABILITIES: ALTERNATIVES TO THE BENCHMARK

\begin{tabular}{|c|c|c|c|c|c|}
\hline \multirow[t]{2}{*}{ Scenario } & \multicolumn{2}{|c|}{ Partial retirement } & \multicolumn{2}{|c|}{ Full retirement } & \multirow[t]{2}{*}{ Probability } \\
\hline & Age & $\%$ Income & Age & $\%$ Income & \\
\hline 1: Postponed retirement & - & & 70 & 90 & 0.04 \\
\hline 2: Postponed retirement & - & & 70 & 100 & 0.13 \\
\hline 3 : Early retirement & & & 62 & 60 & 68.21 \\
\hline 4: Early retirement & & & 62 & 50 & 11.32 \\
\hline 5: Partial retirement & 63 & 85 & 67 & 70 & 66.34 \\
\hline 6: Partial retirement & 63 & 100 & 67 & 70 & 77.79 \\
\hline 7: Partial retirement & 63 & 85 & 67 & 80 & 91.30 \\
\hline 8: Late partial retirement & 65 & 90 & 70 & 90 & 20.12 \\
\hline 9: Late partial retirement & 65 & 100 & 70 & 100 & 47.16 \\
\hline 10: Early partial retirement & 60 & 75 & 65 & 60 & 69.17 \\
\hline
\end{tabular}

Source: (Van Soest et al., 2006, Table 6) Note: "Probability" is the probability that the given scenario is preferred to the benchmark, which is full retirement at age 65 for a $70 \%$ net pension. Simulated probabilities assume no optimization error.

ularly for a high (and actuarially unfair) replacement rate of 60\%. Phased retirement can be made attractive with a high replacement rate after full retirement.

Van Soest et al. (2006) also used their model to simulate choices between early retirement, late retirement, and a scenario involving phased retirement, with hours equal to $60 \%$ of pre-retirement working hours during the phased retirement period. They found that $67 \%$ would prefer early retirement, and $33 \%$ would prefer late retirement if no partial retirement option were available. With partial retirement as a third option, their simulations suggested that $43 \%$ would have chosen partial retirement, $38 \%$ would have chosen early retirement, and 19\% would have chosen late retirement. Total labour supply would increase substantially. Though this outcome depends on many factors (such as the generosity of the hypothetical gradual retirement scheme), it does illustrate the potential of gradual retirement as a tool to increase the labour supply of older people.

Bruinshoofd and Grob (2005) also found that the Dutch are willing to work part-time beyond the normal retirement age (65 years). They analyse a survey question on whether people are willing to work after age 65, without losing their old-age state pension (AOW). While only $2 \%$ of the respondents answer "yes, full-time," $32 \%$ say "yes, part-time." The others answer "no" (57\%) or "do not know" (9\%). This question does not specify the financial compensation for working longer, but other results in the 
same study imply that retirement decisions are quite sensitive to financial incentives.

\section{CONCLUSIONS}

While the descriptive evidence of the prevalence, nature and duration of gradual retirement is abundant for the US, gradual retirement is much less studied in Europe. Part-time work is generally more common among older than among younger workers, but there is substantial variation across countries that remains to be analysed and explained. There is some evidence that financial incentives stimulating gradual retirement will work, but there is scope for incorporating gradual retirement in more rigorous quantitative studies based upon structural models on retirement decisions, like, e.g., Stock and Wise (1990); Gustman and Steinmeier (1986); Blau (1994), or Rust and Phelan (1997). The quantitative impact of policy measures thus remains largely to be determined. Whether they give the same results in different countries also remains to be seen, given the many differences in the institutional settings (e.g. DC and DB pensions, health insurance, housing markets, borrowing constraints, etc.). Data on stated preferences can be a useful tool to disentangle workers' preferences from limitations imposed by employers and institutions. In addition, richer data on actual opportunities and choices are becoming available, for example in the form of register data from the Dutch pension funds.

In Europe and the US, gradual retirement is generally seen as an opportunity to keep older workers longer in the labour market. The few studies that make the quantitative trade-off of the negative- and positive labour supply effects unambiguously conclude that the positive effects dominate: creating more opportunities for gradual retirement can lead to an increase in total labour supply. This makes facilitating gradual retirement attractive from a public policy point of view. The evidence of the effect of gradual retirement on productivity is scarce, but the qualitative conclusions point in the same direction: the older workers who are kept in the labour force are typically well motivated, highly skilled and productive. Gradual retirement can also prevent labour market exit through alternative routes, i.e. unemployment and disability, which is particularly relevant in the Dutch context (see, e.g., Van Vuren and Van Vuuren 2007), particularly if (very) early retirement arrangements are abolished. For workers, the main advantage is a smooth transition to the next stage of life, and an escape from the choice between two inferior options: continuing in a stressful career job with the risk of work disability or full retirement with its negative financial and social consequences. For employers, there seem to be advantages and disadvantages, and not all employers are as yet convinced that gradual retirement should be 
stimulated. However employers seem to realize increasingly that older workers offer valuable experience, can guarantee continuity, and can contribute to the corporate spirit. These advantages may outweigh such potential disadvantages as fixed costs of work and problems in organizing part-time job schedules.

Still, take-up of gradual retirement is rather low in most European countries. Where the mobility in the US labour market accommodates older workers who want to leave their career job to take up a bridge job as a form of partial retirement, this is much less the case in the Netherlands and other European countries. Here phased retirement seems the best option, creating opportunities for part-time work without changing employer.

In addition to (perceived) disadvantages on the employers' side, institutional restrictions imposed by the government or providers of pension plans seem to play a role. Macroeconomic circumstances also matter - gradual retirement is less accepted in times of recession - and policies that jointly consider several exit routes (early retirement, disability, unemployment) are probably preferable. There is room for less stringent rules on combining work with partial-pension receipt, and for more transparency of these rules. In addition, the government can stimulate gradual retirement through transparent tax measures that make gradual retirement more attractive for workers and less expensive for employers. The existing evidence suggests that in the Netherlands, tax favoured arrangements will work - the decision to take up gradual retirement or not is sensitive to financial incentives, like the decision to apply for disability insurance (Van Vuren and Van Vuuren 2007) or the decision to retire (Kapteyn and De Vos 1998). In particular, it seems important to ensure that staying in the labour market as a part-time worker is rewarded in the form of a higher old age pension.

Acknowledgements This paper was commissioned by Netspar for the Netspar Panel debate in October 2007. Research of Tunga Kantarci was funded by the Netherlands Science Foundation, NWO. We are grateful to Hanka Vonkova for excellent research assistance and to two anonymous referees, Marno Verbeek, Jan-Maarten van Sonsbeek, Daniel van Vuuren, Jeanne Bovenberg, and Gerardo Soto y Koelemeijer for useful comments.

Open Access This article is distributed under the terms of the Creative Commons Attribution Noncommercial License which permits any noncommercial use, distribution, and reproduction in any medium, provided the original author(s) and source are credited. 


\section{REFERENCES}

Belloni, M., C. Monticone, and S. Trucchi, (2006), 'Flexibility in Retirement. A Framework for the Analysis and a Survey of European Countries', Research report commissioned by the European Commission', CeRP, Turin.

Blau, D. (1994), 'Labor Force Dynamics of Older Men', Econometrica, 62(1), pp. 117-156.

Brown, K. (2005), 'Attitudes of Individuals 50 and Older Toward Phased Retirement'. Washington, DC, AARP Knowledge Management.

Brückner, H. and K. Mayer (2005), 'De-Standardization of the Life Course: What It Might Mean? And If It Means Anything, Whether It Actually Took Place', in: R. MacMillan (ed.), The Structure of the Life Course: Standardized? Individualized? Differentiated? (Advances in Life Course Research, Volume 9), Amsterdam et al., JAI Elsevier, pp. 27-54.

Bruinshoofd, W.A. and S. Grob (2005), 'Arbeidsparticipatie van Ouderen: Microfinanciële Motivaties en Beleidsaspecten'. DNB Occasional Studies, 3(1), De Nederlandsche Bank, Amsterdam.

Ceelen, M.G.L. (2007), 'De Fiscale en Civielrechtelijke (On)mogelijkheden van Deeltijdpensioen', Competence Centre for Pension Research, Tilburg University.

Chen, Y.-P. and J. Scott (2003), 'Gradual Retirement: An Additional Option in Work and Retirement', North American Actuarial Journal, 7(3), pp. 62-74.

Chen, Y.-P. and J. Scott (2006), 'Phased Retirement: Who Opts for It and Toward What End?', AARP Public Policy Institute, Washington, DC, Research paper 2006-01.

Clark, R. and J. Quinn (2002), 'Patterns of Work and Retirement for a New Century', Generations, 26(2), pp. 17-24.

Delsen, L. (1996), 'Gradual Retirement: Lessons from the Nordic Countries and the Netherlands', European Journal of Industrial Relations, 2(1) (March), pp. 55-67.

Ekerdt, D., S. DeViney, and K. Kosloski (1996), 'Profiling Plans for Retirement', Journal of Gerontology, 51B(3), S140-S149.

Flahaven, B. (2002), 'Please Don't Go! Why Phased Retirement May Make Sense for your Government', Government Finance Review, October 2002.

Forman, J. and P. Scahill (2003), 'Issues for Implementing Phased Retirement in Defined Benefit Plans', North American Actuarial Journal, 7(3), pp. 75-84.

Ghent, L. and R. Clark (2001), 'The Impact of a New Phased Retirement Option on Faculty Retirement Decisions', Research on Aging, 23(6), pp. 671-693.

Gordon, R. and A. Blinder (1980), 'Market Wages, Reservation Wages and Retirement', Journal of Public Economics, 14, pp. 277-308.

Gustman, A. (1985), 'The Effect of Partial Retirement on Wage Profiles of Older Workers,' Industrial Relations, 24(2), pp. 257-265.

Gustman, A. and T. Steinmeier (1982), 'Partial Retirement and Wage Profiles of Older Workers,' NBER Working Papers 1000, National Bureau of Economic Research, Cambridge, MA.

Gustman, A. and T. Steinmeier (1983), 'Minimum Hours Constraints and Retirement Behavior', Contemporary Policy Issues (Supplement to Economic Inquiry), (3) (April), pp. 77-91.

Gustman, A. and T. Steinmeier (1984a), 'Modeling the Retirement Process for Policy Evaluation and Research', Monthly Labor Review, 107(7), pp. 26-33.

Gustman, A. and T. Steinmeier (1984b), 'Partial Retirement and the Analysis of Retirement Behavior', Industrial and Labor Relations Review, 37(3), pp. 403-415.

Gustman, A. and T. Steinmeier (1986), 'A Structural Retirement Model', Econometrica, 54, pp. 555-584. 
Gustman, A. and T. Steinmeier (2000), 'Retirement Outcomes in the Health and Retirement Study', Social Security Bulletin, 63(4), pp. 57-71.

Haider, S. and D. Loughran (2001), 'Elderly Labor Supply: Work or Play?', Working paper 200104, Center for Retirement Research at Boston College.

Hayward, M., M. Hardy, and M.-C. Liu (1994), 'Work after Retirement: The Experiences of Older Men in the United States', Social Science Research, 23(1), pp. 82-107.

Honig, M. (1985), 'Partial Retirement among Women', Journal of Human Resources, 20(4), pp. 613-621.

Honig, M. and G. Hanoch (1985), 'Partial Retirement as a Separate Mode of Retirement Behavior', Journal of Human Resources, 20(1), pp. 21-46.

Hurd, M. (1996), 'The Effect of Labor Market Rigidities on the Labor Force Behavior of Older Workers', in: D. Wise (ed.), Advances in the Economics of Aging, Chicago and London, University of Chicago Press, pp. 11-60.

Hutchens, R. and K. Grace-Martin (2004), 'Who among White Collar Workers Has an Opportunity for Phased Retirement? Establishment Characteristics'. IZA discussion papers 1155, Institute for the Study of Labor, Bonn.

Irelan, L. (1988), 'Retirement History Study: Introduction', Social Security Bulletin, 51(3), pp. 3237.

Kapteyn, A. and K. de Vos (1998), 'Social Security and Labor Force Participation in The Netherlands', American Economic Review Papers and Proceedings, 88, pp. 164-167.

Kim, H. and S. DeVaney (2005), 'The Selection of Partial or Full Retirement by Older Workers', Journal of Family and Economic Issues, 26(3), pp. 371-394.

Kohli, M. (1986), 'Social Organization and Subjective Construction of the Life Course', in: A. Sorensen, F. Weinert and L. Sherrod (eds.), Human Development and the Life Course: Multidisciplinary Perspectives, Hillsdale NJ, Lawrence Erlbaum Associates, pp. 271-292.

Latulippe, D. and J. Turner (2000), 'Partial Retirement and Pension Policy in Industrialized Countries', International Labour Review, 139(2), pp. 179-195.

Maestas, N. (2007), 'Back to Work: Expectations and Realizations of Work after Retirement', RAND L\&P working paper WR 196-2, RAND, Santa Monica.

Mayer, K. and W. Müller (1986), 'The State and the Structure of the Life Course', in: A. Sorensen, F. Weinert and L. Sherrod (eds.), Human Development and the Life Course: Multidisciplinary Perspectives, Hillsdale, NJ, Lawrence Erlbaum Associates Publishers, pp. 217-245.

Mayer, K. and U. Schoepflin (1989), 'The State and the Life Course', Annual Review of Sociology, 15 , pp. $187-209$.

Meyer, J. (1986), 'The Self and the Life Course: Institutionalization and its Effects', in: A. Sorensen, F. Weinert and L. Sherrod (eds.), Human Development and the Life Course: Multidisciplinary Perspectives, Hillsdale, NJ, Lawrence Erlbaum Associates Publishers, pp. 199-216.

Morris, D. and T. Mallier (2003), 'Employment of Older People in the European Union', Labour, 17(4), pp. 623-648.

Mulvey, J. (2005), 'Phased Retirement: IRS Regulations Leave Hurdles To Be Overcome', Balancing Act Newsletter, Washington, DC, Employment Policy Foundation.

Murray, J. (1979), 'Subjective Retirement', Social Security Bulletin, 42(11) (November), pp. 20-25.

Peracchi, F. (2002), 'The European Community Household Panel: A Review', Empirical Economics, 27, pp. 63-90.

Quinn, J. (1981), 'The Extent and Correlates of Partial Retirement', Gerontologist, 21(6) (December), pp. 634-643. 
Quinn, J. (1996), 'The Role of Bridge Jobs in the Retirement Patterns of Older Americans in the 1990s', Boston College working papers in economics 324, Boston College, Department of Economics.

Quinn, J. (1999), 'New Paths to Retirement', in: O. Mitchell, P. Hammond and A. Rappaport (eds.), Forecasting Retirement Needs and Retirement Wealth, Philadelphia, University of Pennsylvania Press, pp. 13-32.

Quinn J., K. Cahill and M. Giandrea (2006), 'Retirement Patterns from Career Employment', Gerontologist, 46, pp. 514-523.

Reday-Mulvey, G. (1995), 'Gradual Retirement in OECD Countries Ageing', International Journal of the International Federation on Ageing, 22(2), pp. 44-48.

Reday-Mulvey, G. (2000), 'Gradual Retirement in Europe', Journal of Aging and Social Policy, 11(2-3), pp. 49-60.

Reday-Mulvey, G. and L. Delsen (1996), 'Gradual Retirement in the OECD Countries: A Summary of the Main Results', Geneva Papers on Risk and Insurance Issues and Practice, 21(81), pp. 502-523.

Roper Starch Worldwide (1999), 'Baby Boomers Envision Their Retirement: An AARP Segmentation Analysis - Executive Summary', Washington, DC, American Association of Retired Persons.

Ruhm, C. (1990), 'Bridge Jobs and Partial Retirement', Journal of Labor Economics, 8(4), pp. $482-501$.

Ruhm, C. (1991), 'Career Employment and Job Stopping', Industrial Relations, 30(2), pp. 193208.

Rust, J. and C. Phelan (1997), 'How Social Security and Medicare Affect Retirement Behaviour in a World of Incomplete Markets', Econometrica, 65(4), pp. 781-831.

Scott, J. (2004), 'Is Phased Retirement a State of Mind? The Role of Individual Preferences in Retirement Outcomes', Paper presented at Population Association of America Annual Meeting, Boston, MA.

Smolkin, S. (1996), 'Phased Retirement, an HR Strategy for an Aging Workforce Creating and Utilizing Flexible Staffing Strategies', Institute for International Research.

Sueyoshi, G. (1989), 'Social Security and the Determinants of Full and Partial Retirement: A Competing Risks Analysis', NBER working paper 3113, National Bureau of Economic Research, Cambridge, MA.

Stock, J. and D. Wise (1990), 'Pensions, the Option Value of Work and Retirement', Econometrica, 58(5), pp. 1151-1180.

Van Soest, A., A. Kapteyn and J. Zissimopoulos (2006), 'Using Stated Preferences Data to Analyze Preferences for Full and Partial Retirement', DNB working paper 081, Netherlands Central Bank, Research Department.

Van Vuren, A. and D. Van Vuuren (2007), 'Financial Incentives in Disability Insurance in The Netherlands', De Economist, 155(1), pp. 73-98.

Wadensjö, E. (2006), 'Part-Time Pensions and Part-Time Work in Sweden', IZA discussion paper no. 2273, Institute for the Study of Labor, Bonn.

Yakoboski, P., P. Ostuw and J. Hicks (1998), 'What Is Your Savings Personality? The 1998 Retirement Confidence Survey', Employee Benefit Research Institute, Issue Brief no. 200, Washington, DC, Employee Benefit Research Institute.

Zweimüller, J. (1993), 'Partial Retirement and the Earnings Test', Journal of Economics, 57(3), pp. 295-303. 